\title{
Brewery sludge quality, agronomic importance and its short-term residual effect on soil properties
}

\author{
E. Alayu ${ }^{1} \cdot$ S. Leta ${ }^{2}$
}

Received: 18 April 2018 / Revised: 4 January 2020 / Accepted: 8 January 2020 / Published online: 23 January 2020

(c) The Author(s) 2020

\begin{abstract}
Wastewater sludge generated from agro-industrial wastewater treatment plants is accepted as a good option for land application as a soil conditioner and substitute mineral fertilizers. However, the quality of the sludge sometimes posed a threat to the surroundings. The objective of the study is to evaluate the biochemical characteristics and fertilizer potential of brewery wastewater sludge for agricultural reuse. A field experiment was conducted in a randomized block design array with three replications using brewery wastewater sludge, and nitrogen, phosphorus and sulfur (NPS) containing commercial fertilizer along with control treatments. The result showed that sludge application significantly increased average above biomass production by $5.7 \%$ and $37.2 \%$ over the NPS and control plots, respectively. Also, the sludge-amended plot produced more grain yield of maize with $26.8 \%$ greater than the control. The brewery sludge temporary residual effect analysis revealed that the addition of the sludge led significant changes in soil $\mathrm{pH}$ reduction and soil electrical conductivity, total phosphorus, total nitrogen and total potassium increment as compared to others and background concentration. Similarly, lead and fecal coliform concentrations in the sludge-amended soil showed $150 \%$ and $24.4 \%$ increments, respectively, over the control. In general, the preliminary sludge temporary residual effect analysis showed an encouraging outcome on soil basic properties and maize crop productivity. Conversely, future long-term study is essential to monitor the effect of soil salinity, heavy metal and pathogen contaminations on soil and crop production.
\end{abstract}

Keywords Brewery wastewater sludge management $\cdot$ Recycling sludge essential nutrients $\cdot$ Maize biomass and grain yield $\cdot$ Sludge temporary residual effect

\section{Introduction}

Agro-industrial divisions in Ethiopia are rapidly increasing and posing a considerable environmental pollution problem (Alayu and Yirgu 2017). The brewery industry is the one that discharges large volumes of wastes (i.e., hot trub, spent grain, yeast cells, kieselguhr and wastewater sludge) that

Editorial responsibility: M. Abbaspour.

\author{
E. Alayu \\ ermias.alayu@gmail.com \\ S. Leta \\ seyoum.leta@aau.edu.et \\ 1 Department of Chemistry, College of Natural \\ and Computational Science, Assosa University, Asosa, \\ Ethiopia
}

2 Centre for Environmental Science, College of Natural Science, Addis Ababa University, Addis Ababa, Ethiopia encompasses higher strength organic pollutants (Spinosa and Vesilind 2001; Kanagachandran and Jayaratne 2006), which are hazardous to the environment (Rajagopal et al. 2013; Omoyeni and Moronkola 2012). Wastewater sludge disposal causes environmental hygienic problems (Hseu 2004). Hence, disposal of these wastes in an environmentally sustainable way has got universal attention (Asia et al. 2008) and has great importance to the resident public, consultants and the industry. In Ethiopia, most agro-industries particularly brewery industries released their huge volume of wastewaters with little or without treatment. Hence, beverage industries in Ethiopia are known for their environmental pollution by releasing untreated or partially treated effluents into nearby water bodies and soil matrices (Oljira et al. 2017). In the current times, some brewery factories in Ethiopia planted anaerobic-aerobic integrated treatment systems to manage their organic-rich wastewaters. Nevertheless, sludges produced from treatment plants bring a substantial burden on the environment. For instance, the 
aerobic treatment unit of Kombolcha brewery generates $25 \mathrm{~m}^{3}$ of sludge per day and dumping into the surrounding open land. But, currently, the sludge handling process has become an increasing urgency problem in the factory due to limited land disposal space. Not only this, if the sludge is not properly managed, potential risks to both the environment and public health may occur from the accumulation of trace metals and organic compounds, as well as pathogen contamination in the future (Babel et al. 2009). Therefore, sludge disposal should be managed in an eco-friendly manner (Fillaudeau et al. 2006; Thomas and Rahman 2006). Different sludge disposal mechanisms are suggested by different researchers, but sludge recycling for land application is an alternative option to escaping the high landfill cost and available land space restriction in addition to hygienic problems (Hseu 2004).

Many research investigations demonstrated that agroindustrial wastewater sludges have unrestricted importance for agricultural reuse as an organic fertilizer and substitute mineral fertilizers for more crop productivity without any hazardous effect (López-mosquera and Carral 2000; Dolgen et al. 2004; Omoyeni and Moronkola 2012; Ramya et al. 2015). There are also insufficient scientific pieces of evidence in Ethiopia on the application of brewery sludge for the increment of productivity of different crops through supplying nutrients. Alemu et al. (2017) conducted a field trial in Daker, Harari regional state of eastern Ethiopia using different ratios of brewery sludge and commercial fertilizer to grow sorghum. Results demonstrated that 15 tons per hectare $\left(\mathrm{tha}^{-1}\right.$ ) of brewery sludge (BS)-amended sorghum plot produces more crop yield than that of NPS commercial fertilizer. In line with this, Wendimagegn (2016) has also reported that the addition of $2.5 \%$ BS produced more tomato fruits (16.33) as compared with the supplying of an equivalent dose of urea. The achievement of improved tomato fruits from the sludge-treated plot may be associated with the occurrence of essential plant nutrients such as total nitrogen (TN), total phosphorus (TP) and potassium (K) (Erdem and Suzudogru-Ok 2002; Jolly and Ashwani 2012). However, wastewater sludges are dynamic in characteristics which vary widely by original wastewater composition and wastewater treatment courses, along with sludge treatment processes; hence, wastewater sludge may contain additional toxic substances that cause harmful effects to soil microbial activities through transfer of antibiotics in the soil environment (Chen et al. 2016) and humans through transmission in the food chain (Arthurson 2008) when they are applied for agricultural uses.

Therefore, the characterization of the BS quality is vital to conclude on its viability for recycling it for agricultural application to promote waste resource utilization besides environmental protection. The former brewery wastewater sludge quality characterization result shows that the sludge has a high content of organic matter (OM), high total nitrogen (TN) and total phosphorus (TP); optimal $\mathrm{pH}$ and salinity level including plant secondary nutrients $\left(\mathrm{Ca}^{2+}, \mathrm{Mg}^{2+}\right.$, $\mathrm{Na}^{+}$and $\mathrm{K}^{+}$) values (Table 1 ). In addition to these, the concentration of the very lower heavy metals (Table 2) meets the required standard limits and can be safely used as a valuable organic fertilizer without risk. However, the higher observed pathogens require additional treatment to the acceptable limit for unrestricted reuse (Alayu et al. 2018). Besides this, the study was objectively carried out to assess the agronomic importance of the sludge to cultivate maize crop and its short-term residual effect on basic soil properties. In general, two basic questions have been answered in this research: (1) Does BS can substitute the commercial fertilizer at an equivalent rate supplying with
Table 1 Physical and biochemical properties of BS and background soil samples

\begin{tabular}{|c|c|c|c|c|}
\hline \multirow[t]{2}{*}{ Parameters } & \multicolumn{2}{|l|}{ BS } & \multicolumn{2}{|c|}{ Background soil } \\
\hline & Mean & Mean \pm SD & Mean & Mean \pm SD \\
\hline $\mathrm{pH}$ & 7.85 & $7.85 \pm 0.005$ & 6.99 & $6.99 \pm 0.02$ \\
\hline $\mathrm{EC}(\mu \mathrm{S} / \mathrm{cm})$ & 2352.67 & $2352.67 \pm 2.52$ & 47.1 & $47.10 \pm 2.58$ \\
\hline WHC $(\%)$ & 54.0 & $54.0 \pm 1.00$ & - & - \\
\hline $\mathrm{OC}(\%)$ & 49.10 & $49.10 \pm 0.10$ & - & - \\
\hline $\mathrm{OM}(\%)$ & 84.65 & $84.65 \pm 0.17$ & - & - \\
\hline $\mathrm{TN}(\%)$ & 3.84 & $3.84 \pm 0.04$ & 1.75 & $1.75 \pm 0.32$ \\
\hline $\mathrm{P}_{2} \mathrm{O}_{5}(\%)$ & 5.92 & $5.92 \pm 0.01$ & 0.024 & $0.024 \pm 0.01$ \\
\hline $\mathrm{K}^{+}(\mathrm{mg} / \mathrm{kg})$ & 1.61 & $1.61 \pm 0.38$ & 0.02 & $0.02 \pm 0.0 .01$ \\
\hline $\mathrm{Na}^{+}(\mathrm{mg} / \mathrm{kg})$ & 0.37 & $0.37 \pm 0.02$ & 1.00 & $1.00 \pm 0.08$ \\
\hline $\mathrm{Ca}^{2+}(\mathrm{mg} / \mathrm{kg})$ & 3.19 & $3.19 \pm 0.34$ & 0.16 & $0.16 \pm 0.0 .06$ \\
\hline $\mathrm{Mg}^{2+}(\mathrm{mg} / \mathrm{kg})$ & 1.19 & $1.19 \pm 0.26$ & 1.09 & $1.09 \pm 0.0 .02$ \\
\hline TFC (MPN/ml, as FW) & $5.46 \times 10^{6}$ & $5.46 \times 10^{6} \pm 0.02$ & - & - \\
\hline $\mathrm{TFC}(\mathrm{MPN} / \mathrm{ml}$, as DW) & $3.06 \times 10^{4}$ & $3.06 \times 10^{4} \pm 0.01$ & - & - \\
\hline
\end{tabular}

FW (fresh weight) and DW (dry weight) pathogen content of the sludge 
Table 2 Concentrations of detected heavy metals in BS and recommended standard limits for agricultural reuse

\begin{tabular}{llllll}
\hline Heavy metals & $\begin{array}{l}\text { The concentration of } \\
\text { metals }(\mathrm{mg} / \mathrm{kg})\end{array}$ & & \multicolumn{2}{l}{ Standard $(\mathrm{mg} / \mathrm{kg})$} \\
\cline { 2 - 3 } \cline { 5 - 6 } & Mean & Mean $\pm \mathrm{SD}$ & & CCME limit $^{1}$ & ${\text { EPA } \text { imit }^{2}}^{2}$ \\
\hline $\mathrm{Zn}$ & 0.07 & $0.07 \pm 0.02$ & & 700 & 7500 \\
$\mathrm{~Pb}$ & 0.05 & $0.05 \pm 0.01$ & & 150 & 840 \\
$\mathrm{Cu}$ & 0.77 & $0.77 \pm 0.05$ & & 400 & 4300 \\
$\mathrm{Fe}$ & $10,211.5$ & $10,211.5 \pm 10$ & - & - \\
\hline
\end{tabular}

${ }^{1}$ Canadian Council of Ministers of the Environment (1995); no limits in use; ${ }^{2}$ United State Environmental Protection Authority (1994) ceiling limits for all sludge applied to land

the recommended rate of $38 \%$ phosphorus to the local soil and safe for maize productivity? And (2) is adding this equivalent rate of BS cause positive or negative effect on basic soil properties?

The study was conducted in Amhara Regional State, the northern part of Ethiopia during the 2017 main cropping season on the farmers' field under normal rainfed condition. The area is geographically located between latitude $11^{\circ} 04^{\prime}$ $00^{\prime \prime} \mathrm{N}$ and longitude $039^{\circ} 43^{\prime} 505^{\prime \prime} \mathrm{E}$.

\section{Materials and methods}

\section{Design of the experimental}

A randomized block array experimental design was used with three replications (total of nine treatment plots). Field plots $(5 \mathrm{~m} \times 6 \mathrm{~m})$ were used for BS, commercial fertilizer (i.e., NPS) and control treatments for the study purpose with $100-\mathrm{cm}$ paths separating between blocks. Each three field plots were amended with 0.96 tha $^{-1}$ equally sized BS considering $20 \%$ directly available phosphorus content to obtain a rough estimate replacement value to the $38 \%$ phosphorus content of the NPS fertilizer to enhance the limited phosphorus content of the local soil (Table 1), whereas the other three plots were treated with 0.1 tha $^{-1}$ NPS fertilizer and the remaining three plots were left as a control. The experimental site was clean, and each plot was well prepared by plowing and upsetting before subjected to treatment. The dried brewery wastewater sludge treatment was applied at 14 days before planting and mixed up to the plow depth of soil in a row. Similarly, the required rate of NPS as half of the nitrogen and full rate of the phosphorus were applied to the NPS fertilizer treatment plots at a time of planting. Three maize (Zea mays L.) seeds were propagated per hill in rows of six per treatment plot at a spacing of $25 \mathrm{~cm}$ by $70 \mathrm{~cm}$ between seeds and rows, respectively, on July 14, 2017 and later watered down to one seedling per hill. The second half of the nitrogen fertilizer (urea) was applied 25th day after planting at the NPS fertilizer-treated plots. Weeding was done manually regularly at a time of weed growth.

\section{Yield component and grain yield measurement}

Maize yield components (i.e., the height of maize plant, stalk diameter of maize, maize leaf height and number of leaves) and grain yield were measured following the standard procedures. From the middle rows, ten plants were tagged randomly for yield component, while five plants were tagged simultaneously for biomass yield measurement. The height of the maize plants was measured to the nearest centimeter starting from the base to top; the maize stalk diameters to the nearest centimeter at the base; and leaf heights to the nearest centimeter from its base to the top. Some leaves per plant for the tagged maize plants were also counted at three stages (i.e., seedling/knee, flowering and maturation). The biomass yield of the tagged maize plants was determined by harvesting the above-ground maize parts and drying in an oven at $70{ }^{\circ} \mathrm{C}$ for 3 days. At that time, the measured values for each parameter were summed and taken as the average score. The total maize grain yield of all the treatment plots was carefully harvested from the middle rows and threshed for full yield recovery per treatment plot. The grain yield (airdried) was computed in tha ${ }^{-1}$ based on the total population of plants $(32,000)$ per hectare using the relevant variables.

$\mathrm{GY}_{\mathrm{ha}}=Y_{\mathrm{p}} \times P_{\mathrm{ha}}$

where $\mathrm{GY}_{\mathrm{ha}}=$ grain yield per hectare, $Y_{\mathrm{p}}=$ average grain yield per plant and $P_{\mathrm{ha}}=$ plant population per hectare.

\section{Sludge short-term residual effect analysis}

Before starting and after harvest, composite soil samples were collected from 0 to $20 \mathrm{~cm}$ depth from all the experimental plots. The composite soil samples were well-mixed and air-dried. The well-mixed samples were divided into $1 \mathrm{~kg}$ to obtain a representative sample for basic soil property analysis. Then, the soil sample was powdered to $<2 \mathrm{~mm}$ size using mortar and pestle, and it was then stored in the sterilized plastic bag for laboratory analysis.

\section{Determination of basic soil properties}

Three replicates of composite soil samples were taken for the measurement of their basic properties. The $\mathrm{pH}$ and EC were measured from the soil/distilled water extract saturated paste (1:2.5) (Government of Maharashtra 2009); the WHC was measured by Skene et al. (1995); total solid content (TS) and total fecal coliforms (TFC) were determined 
following APHA method (1999); total nitrogen (TN) was determined using the Kjeldahl method (Bremner and Mulvaney 1982); and available phosphorus was determined by $\mathrm{NaHCO}_{3}$-ascorbic acid method using UV-visible spectroscopy at wavelength of $882 \mathrm{~nm}$ (Olsen et al. 1954). Organic carbon (OC) was measured by the loss ignition method (Almahasneh et al. 2008). Estimation of organic matter (OM) from determined organic carbon (OC) of soil using a single conversion factor is difficult (Pribyl 2010). In this study, SOM content was estimated by multiplying SOC by conventional factor (i.e., 1.724). For metal analysis, the ground soil sample $(1 \mathrm{~g})$ was placed in $25-\mathrm{ml}$ beakers, and next, $10 \mathrm{ml} \mathrm{HNO}_{3}(69-70 \%)$ and $10 \mathrm{ml} \mathrm{HCl} \mathrm{(35.4 \% )} \mathrm{(Mumbai,}$ India) were added along with $30 \% \mathrm{H}_{2} \mathrm{O}_{2}$ (Scharlau, European Union) following Method 3050 (Edgell 1989). Selected soluble salts were used to prepare standard solutions for each element, and a calibration curve was drawn from them in the instrument before unknown samples were used (Table 3 ). Then, the total metal concentrations were determined using atomic absorption spectrometer (Shimadzu AA-7000, Japan) at specific wavelength $(\mathrm{nm})$ region and detection limits (DL) of 324.8 and 0.035 for copper $(\mathrm{Cu}) ; 283$ and 0.01 for lead $(\mathrm{Pb}) ; 213.9$ and 0.012 for zinc $(\mathrm{Zn}) ; 248$ and 0.08 for iron (Fe); 239 and 0.0035 for calcium $(\mathrm{Ca}) ; 285.2$ and 0.035 for magnesium $(\mathrm{Mg}) ; 766.5$ and 0.02 for potassium $(\mathrm{K})$; and 589 and 0.007 for sodium $(\mathrm{Na})$, respectively.

\section{Statistical data analysis}

All the randomized complete block design experimental measurement data statistical analysis $($ at $p<0.05$ ) and graphs were analyzed using OriginPro2017 software and Microsoft excel 2010.

Table 3 Calibration point of the standards

\begin{tabular}{ll}
\hline Parameters & Regression equation and $r^{2}$ value \\
\hline $\mathrm{K}$ & $y=0.3648 x+3 \mathrm{E}-05, r^{2}=1$ \\
$\mathrm{Na}$ & $y=0.0681 x+3 \mathrm{E}-05, r^{2}=1$ \\
$\mathrm{Mg}$ & $y=0.0188 x+2 \mathrm{E}-16, r^{2}=1$ \\
$\mathrm{Ca}$ & $y=0.6975 x+0.115, r^{2}=0.9975$ \\
$\mathrm{Cu}$ & $y=0.8191 x-0.0234, r^{2}=0.9905$ \\
$\mathrm{Zn}$ & $y=0.393 x-0.0102, r^{2}=0.989$ \\
$\mathrm{~Pb}$ & $y=0.0582 x-0.0021, r^{2}=0.9911$ \\
$\mathrm{Phosphorus}$ & $y=0.3214 x+0.0069, r^{2}=0.9988$ \\
\hline
\end{tabular}

\section{Results and discussion}

\section{Yield component measurement data}

The yield component parameters of maize plants were assessed by measuring the plant height, stalk diameter, leaf height as well as some leaves for all treatment groups. Relatively maximum number of leaves (NL) were counted from the BS-amended plots (i.e., 4.3, 8.2 and 11.2) over the control (i.e., 3.6, 7.5 and 8.5) and NPS inorganic fertilizer (i.e., $4,7.9$ and 10.1)-fertilized plots (Fig. 1a) at each measurement period. A significant $(p=0.03739)$ increment in NL was observed in the BS-amended plot as compared to control at the maturation measurement stage. Similarly, maximum mean value of plant height was obtained from the brewery sludge-treated plot (i.e., 60.8, 162.8 and $192.4 \mathrm{~cm}$ ) than the plant height of NPS (PHNPS) fertilizer and control (PHC) plot values of $(57.9,156.2$ and $182 \mathrm{~cm})$ and $(56.5,154.3$ and $171.4 \mathrm{~cm})$, respectively, at each measurement period. The highest plant height as mean was $192.4 \mathrm{~cm}$ per plot found in the BS-treated plot. Alternatively, the lower plant heights were recorded from the NPS-fertilized and control plots at each measurement stage. Application of BS with equivalent dosing rate to NPS fertilizer showed significant changes in the average plant height at flowering $(p=0.02405)$ and maturity ( $p=1.44974 \mathrm{E}-5)$ as compared to the control. Similarly, the average plant height of brewery sludge (PHBS) showed a significant $(p=7.90951 \mathrm{E}-4)$ difference as compared to the NPS fertilizer-fertilized plots. In general, the application of BS showed average percentage increments of $5 \%$ and $8.85 \%$, respectively, in plant height over the NPS-fertilized and control plots (Fig. 1b) at the end of all measurement stages. These maize plant heights and the number of leaves increment may be arising from the decomposition of nutrients from the application of BS which could enhance in crop cell elongation and division as a result of available essential nutrients for the growth of the plants. The PHBS obtained in the present result argued Cheraghi et al. (2015) findings, and the sewage sludge-treated plot recorded higher plant length of fenugreek (Trigonella gracum) as compared to chemical fertilizer-treated and control plots. This suggests that the more available nutrients present in the BS sludge are enough to plant growth demands.

The measurement of stalk diameter of BS (SDBS) showed insignificant changes $(p=0.07391)$ over the stalk diameters of NPS (SDNPS) fertilizer-treated and stalk diameter of control (SDC) plots at each measurement modes. In this line, the average stalk diameter of the maize plant measured from the BS-treated plots was $3 \mathrm{~cm}, 7.8 \mathrm{~cm}$ and $10.9 \mathrm{~cm}$, respectively, at the seedling/ knee, flowering and maturation stages, whereas the stalk 
(a)

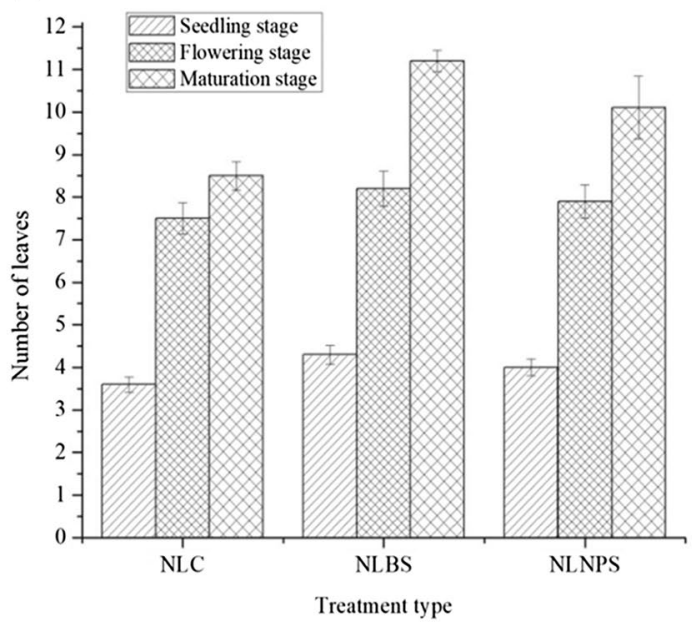

(c)

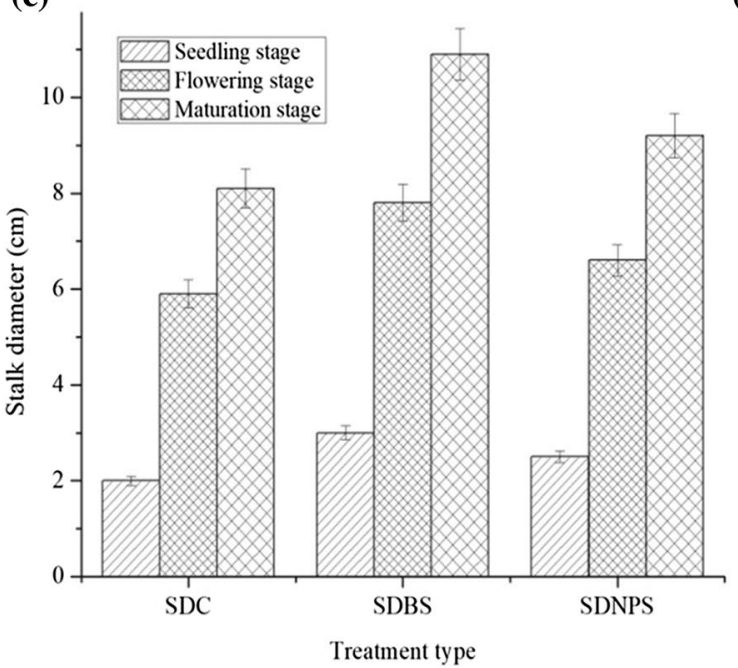

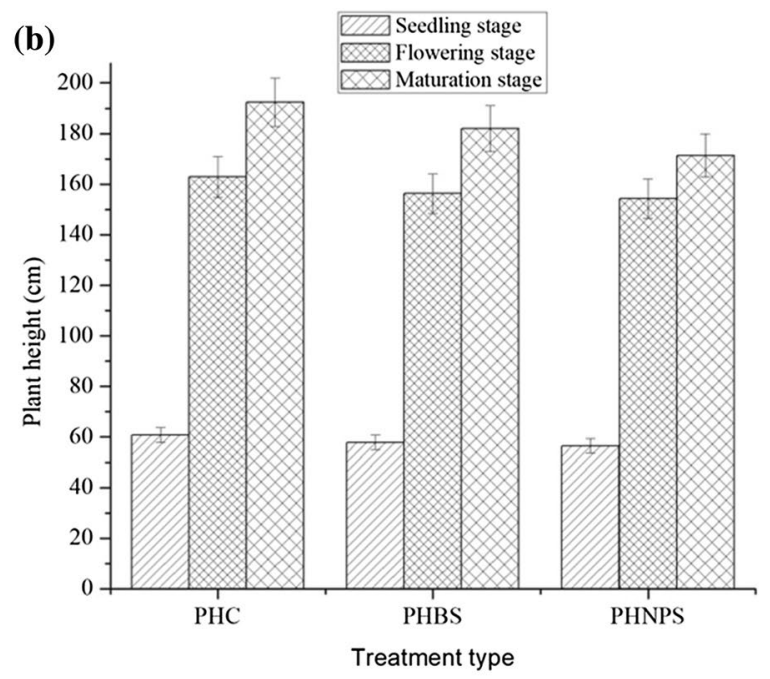

(d)

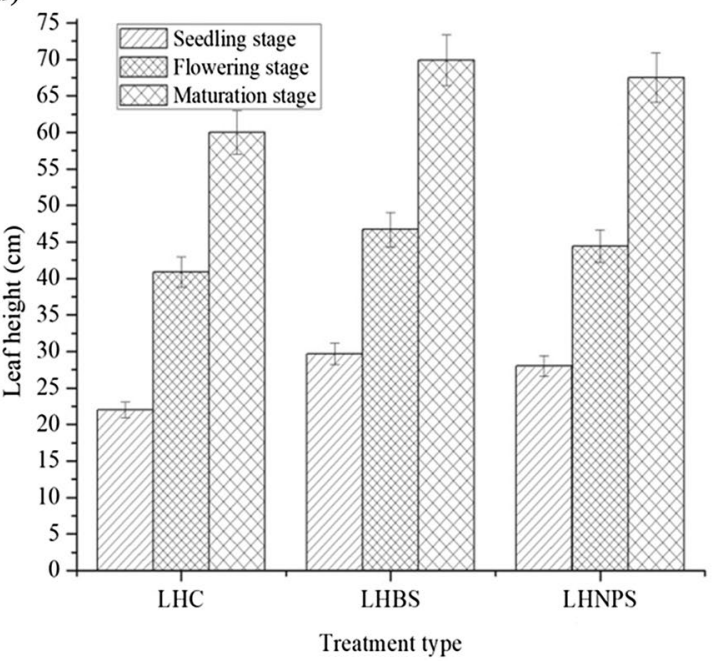

Fig. 1 Effect of brewery sludge application on the a number of leaves, $\mathbf{b}$ plant height, $\mathbf{c}$ stalk diameter and $\mathbf{d}$ leaf height of maize plant

diameter of the maize plant obtained from the NPS-treated and control plots was ranging from 2.5 to $9.2 \mathrm{~cm}$ and 2 to $8.1 \mathrm{~cm}$, respectively (Fig. 1c). Regarding the leaf height, the highest leaf height on average was obtained in the BS (LHBS)-treated plot (i.e., $29.7 \mathrm{~cm}, 46.8 \mathrm{~cm}$ and $69.9 \mathrm{~cm}$ ) as compared to the leaf height of NPS fertilizer (LHNPS) $(28 \mathrm{~cm}, 44.4 \mathrm{~cm}$ and $67.5 \mathrm{~cm})$ and leaf height of control (LHC) $(22 \mathrm{~cm}, 40.9 \mathrm{~cm}$ and $60 \mathrm{~cm}$ ) plots (Fig. 1d) during the entire measurement period. In this respect, the application of BS gave a maximum leaf height at all measurement periods, which varies significantly as compared with the leafy heights of control plots at all measurement periods. In general, better average maize yield component growth characteristics were observed under the brewery sludgetreated plot than the NPS fertilizer and control plots. These significant differences in leaf height, plant height and the number of leaves of maize plants confirm that the application of BS can promote maize growth by supplying essential plant nutrients. Likely to the present finding, Akongwubel et al. (2012) confirmed that the increasing application of poultry manure provided larger yield component growths of maize (Z. mays L.) plant due to greater availability of macro- and micronutrients in the poultry manure.

\section{Total biomass and grain yield}

The above-ground total biomass of maize (as dry weight) and total grain yield of all treatment plots are summarized in Table 4. The total biomass (expressed as leaf and stem dry weight) measurement results showed a significant $(p<0.05)$ variations between the treatment plots. The leaf 
Table 4 Effect of BS application on the biomass and yield of maize

\begin{tabular}{llll}
\hline Treatment type & \multicolumn{2}{l}{ Plant biomass } & \\
\cline { 2 - 4 } & Leaf dry weight $(\mathrm{g})$ & Stem dry weight $(\mathrm{g})$ & Grain yield $\left(\right.$ tha $\left.^{-1}\right)$ \\
\hline Control & 38.2 & 217.1 & 2.61 \\
BS & 57.5 & 292.8 & 3.31 \\
NPS fertilizer & 49.9 & 281.4 & 2.94 \\
$p$ value $($ at $p<0.05)$ & $7.98642 \mathrm{E}-4$ & $5.80942 \mathrm{E}-9$ & 0.00759 \\
\hline
\end{tabular}

(a)

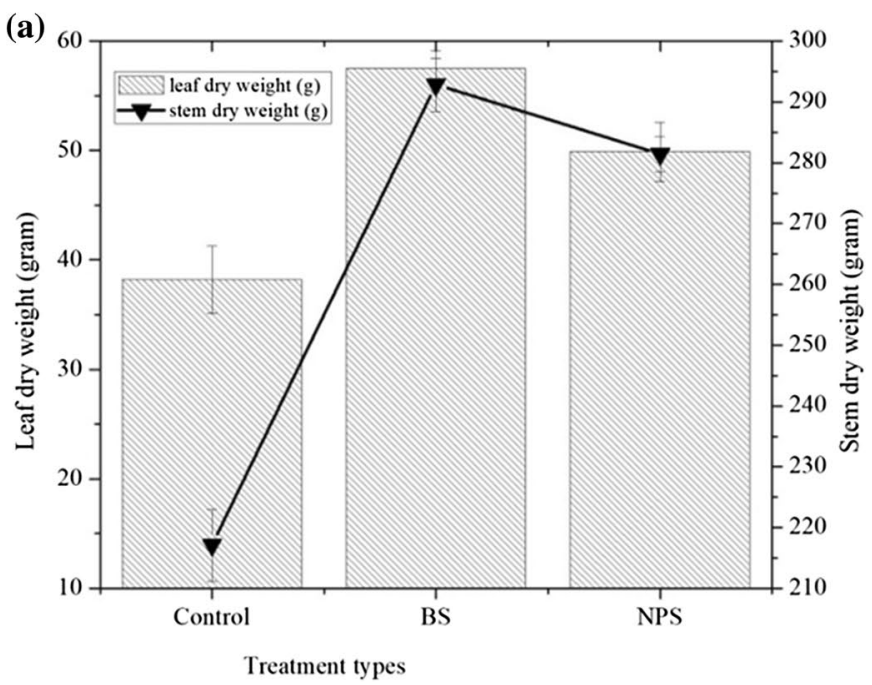

Fig. 2 a Biomass and $\mathbf{b}$ grain yield of the maize plant

and stem biomass of maize crops obtained from the BStreated plot gave relatively greater biomass of leaf $(57.5 \mathrm{~g})$ and stem (292.8 g) as compared to the control and NPSfertilized plots (Table 4 and Fig. 2a). This result agrees with the report of Akongwubel et al. (2012), who observed a significant increment in leaf (53.6 g) and stem (294.3 g) dry matter accumulation during the 2005 cropping season in maize at 8 tha $^{-1}$ application of poultry manure. Overall, the application of BS showed significant differences in average total above biomasses between the treatment groups with a total biomass yield increment of $37.2 \%$ and $5.7 \%$ over the control and NPS-fertilized plots, respectively. Similarly, the application of BS with equivalent dosing rate to NPS fertilizer showed a slight increment in the total grain yield of the maize plant. In general, the BS-amended plot brought a relatively higher grain yield (3.31 tha $\left.\mathrm{th}^{-1}\right)$, which significantly varies with the control $(p=3.39559 \mathrm{E}-4)$ and NPS $(p=0.00944)$-treated plot grain yields (Table 4 and Fig. $2 b$ ) including missing. In this regard, BS-amended plot produced 12.6 and $26.8 \%$ more grain yield than that of NPS-fertilized and control plots, respectively. The maize grain yield obtained in this study observing the reported result of sorghum grain yield of 3.282 tha $^{-1}$ obtained at 10 tha $^{-1}$ brewery sludge
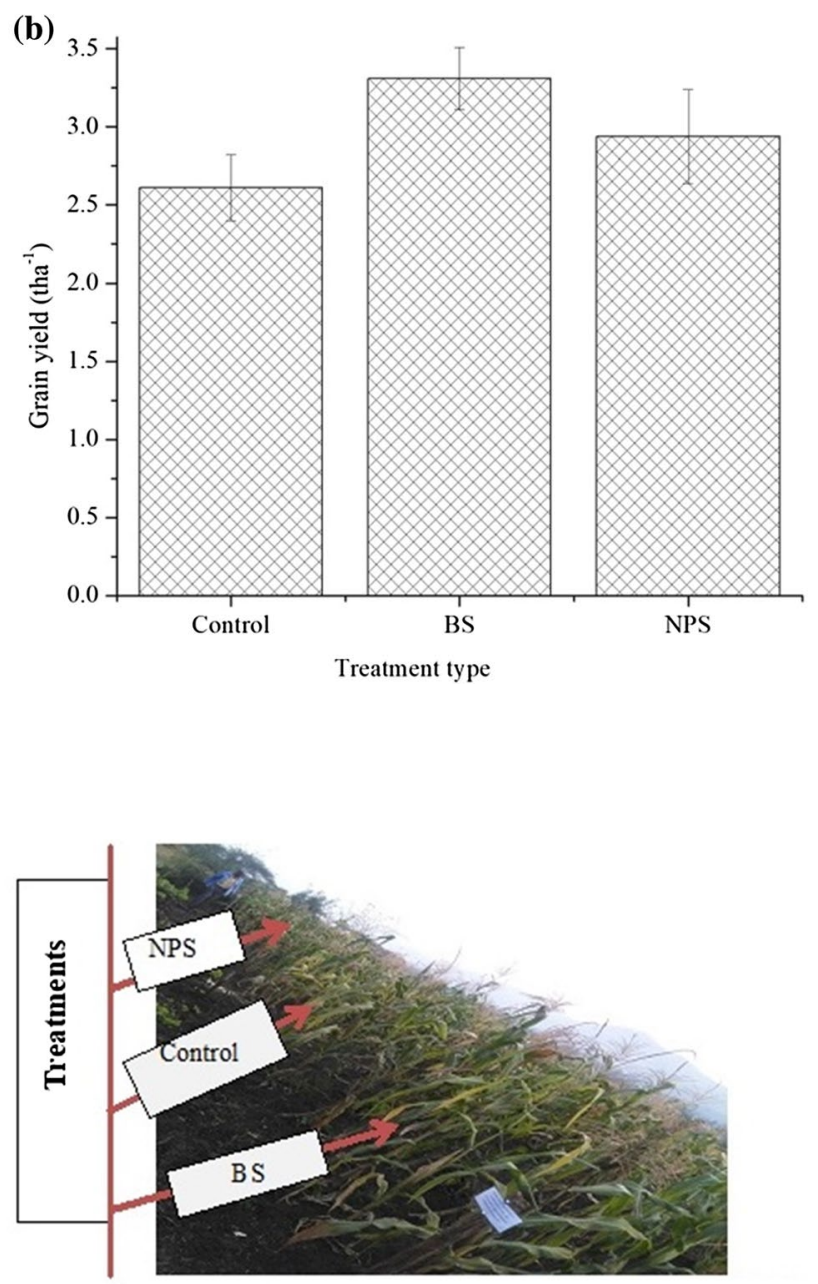

NPS $=$ Nitrogen, Phosphorus and Sulfur containing commercial fertilizer BS $=$ Brewery Sludge

Fig. 3 Photograph of maize (one side laid front view)

application (Alemu et al. 2017), and they also reported that further addition of brewery sludge from 2.5 to 15 tha $^{-1}$ increases the sorghum crop productivity from 2.07 to 4.08 tha $^{-1}$, respectively. The observed significant difference found in average biomass and grain yield of maize plants under the sludge-treated plot could be due to the ability of the brewery sludge to provide essential nutrients (especially nitrogen, phosphorus and potassium) necessary to promote the biomass and grain yield (Fig. 3). 
Table 5 Sludge short-term residual effect on soil physical, and biochemical properties

\begin{tabular}{|c|c|c|c|c|c|c|c|}
\hline \multirow[t]{2}{*}{ Soil properties } & \multicolumn{2}{|c|}{ Control plots } & \multicolumn{2}{|c|}{ BS-amended plots } & \multicolumn{2}{|c|}{ NPS-amended plots } & \multirow[t]{2}{*}{$p$ Value } \\
\hline & Mean & Mean \pm SD & Mean & Mean \pm SD & Mean & Mean \pm SD & \\
\hline $\mathrm{pH}$ & 7.02 & $7.02 \pm 0.01$ & 6.74 & $6.74 \pm 0.22$ & 6.98 & $6.98 \pm 0.005$ & $8.18332 \mathrm{E}-8$ \\
\hline $\mathrm{EC}(\mu \mathrm{S} / \mathrm{cm})$ & 47.66 & $47.66 \pm 2.58$ & 306.5 & $306.5 \pm 7.4$ & 140.1 & $140.1 \pm 2.2$ & $1.00386 \mathrm{E}-10$ \\
\hline WHC (\%) & 83.25 & $83.25 \pm 1.42$ & 86.5 & $86.5 \pm 3.00$ & 83.45 & $83.45 \pm 1.98$ & $0.35752 *$ \\
\hline $\mathrm{OC}(\%)$ & 50.17 & $50.17 \pm 0.11$ & 51.47 & $51.47 \pm 0.16$ & 50.16 & $50.16 \pm 0.13$ & $0.25954 *$ \\
\hline $\mathrm{OM}(\%)$ & 86.49 & $86.49 \pm 0.19$ & 88.74 & $88.74 \pm 0.16$ & 86.47 & $86.47 \pm 0.28$ & $0.05066^{*}$ \\
\hline $\mathrm{TN}(\%)$ & 1.87 & $1.87 \pm 0.32$ & 2.52 & $2.52 \pm 0.28$ & 2.14 & $2.14 \pm 0.43$ & $6.30278 \mathrm{E}-4$ \\
\hline $\mathrm{TP}(\mathrm{ppm})$ & 106.1 & $106.10 \pm 01.32$ & 203.7 & $203.70 \pm 8.03$ & 106.2 & $106.25 \pm 1.32$ & $3.17519 \mathrm{E}-9$ \\
\hline $\mathrm{P}_{2} \mathrm{O}_{5}(\mathrm{ppm})$ & 242.9 & $242.97 \pm 16.25$ & 466.5 & $466.5 \pm 18.38$ & 243.3 & $243.31 \pm 3.01$ & $1.96066 \mathrm{E}-10$ \\
\hline $\mathrm{K}(\mathrm{mg} / \mathrm{kg})$ & 0.03 & $0.03 \pm 0.02$ & 0.69 & $0.69 \pm 0.08$ & 0.53 & $0.53 \pm 0.22$ & $1.53132 \mathrm{E}-4$ \\
\hline $\mathrm{Na}(\mathrm{mg} / \mathrm{kg})$ & 0.91 & $0.91 \pm 0.08$ & 1.22 & $1.22 \pm 0.19$ & 1.12 & $1.12 \pm 0.0 .13$ & 0.02326 \\
\hline $\mathrm{Ca}(\mathrm{mg} / \mathrm{kg})$ & 0.13 & $0.13 \pm 0.07$ & 0.20 & $0.20 \pm 0.01$ & 0.17 & $0.17 \pm 0.01$ & $0.70546^{*}$ \\
\hline $\mathrm{Mg}(\mathrm{mg} / \mathrm{kg})$ & 1.12 & $1.12 \pm 0.02$ & 1.19 & $1.19 \pm 0.07$ & 1.16 & $1.16 \pm 0.00$ & $0.70546^{*}$ \\
\hline$C / N$ ratio & 26.83 & & 20.42 & & 23.44 & & $6.96107 \mathrm{E}-4$ \\
\hline TFC (MPN/g) & $0.37 \times 10^{2}$ & $0.37 \times 10^{2} \pm 0.01$ & $0.94 \times 10^{3}$ & $0.94 \times 10^{3} \pm 0.01$ & $0.34 \times 10^{2}$ & $0.34 \times 10^{2} \pm 0.01$ & $1.86722 \mathrm{E}-6$ \\
\hline Zn (mg/kg) & 0.17 & $0.17 \pm 0.03$ & 0.22 & $0.22 \pm 0.01$ & 0.13 & $0.13 \pm 0.00$ & $0.57391 *$ \\
\hline $\mathrm{Fe}(\mathrm{mg} / \mathrm{kg})$ & 0.70 & $0.70 \pm 0.07$ & 1.91 & $1.91 \pm 0.11$ & 1.19 & $1.19 \pm 0.19$ & $0.24513 *$ \\
\hline $\mathrm{Cu}(\mathrm{mg} / \mathrm{kg})$ & 0.04 & $0.04 \pm 0.03$ & 0.06 & $0.06 \pm 0.01$ & 0.05 & $0.05 \pm 0.01$ & $0.125^{*}$ \\
\hline $\mathrm{Pb}(\mathrm{mg} / \mathrm{kg})$ & 0.38 & $0.38 \pm 0.42$ & 0.95 & $0.95 \pm 0.11$ & 0.37 & $0.37 \pm 0.02$ & $5.75341 \mathrm{E}-4$ \\
\hline ML & \multicolumn{7}{|c|}{$200 \mu \mathrm{g} / \mathrm{g}$ for $\mathrm{Zn}, 50 \mu \mathrm{g} / \mathrm{g}$ for $\mathrm{Cu}$ and $300 \mu \mathrm{g} / \mathrm{g}$ for $\mathrm{Pb}$} \\
\hline
\end{tabular}

*Insignificant differences (at $p>0.05$ ) between the treatment groups, ML= maximum limits of heavy metals in the soil (USEPA 1997)

\section{Sludge short-term residual effect on soil properties}

Table 5 indicates the result of the physical and biochemical properties of the brewery wastewater sludge and NPStreated plot soils along with control. The sludge-treated plot soil commonly showed a significant variation in soil potential hydrogen $(\mathrm{pH})$, electrical conductivity (EC), total nitrogen, total phosphorus, available phosphorus and potassium when compared to the NPS and control soils, whereas insignificant changes were observed in terms of organic carbon, organic matter, water-holding capacity, $\mathrm{Ca}^{2+}$ and $\mathrm{Mg}^{2+}$ ions. As indicated in Fig. $4 \mathrm{a}$, the $\mathrm{pH}$ of the brewery sludge-amended plot soil exhibited a greater percentage reduction from a background $\mathrm{pH}$ value of 6.99, while the NPS and control keep almost constant. Corresponding to this finding, Ramya et al. (2015) also detected in the reduction of $\mathrm{pH}$ of sandy soil from 8.36 to 7.51 due to the addition of brewery sludge. The probable reason for this reduction may be due to the productions of organic acids from brewery sludge organic residues through degradation (Erdem and Suzudogru-Ok 2002). The EC of the brewery wastewater sludge-amended plot soil was $0.306 \mathrm{mS} / \mathrm{cm}$ which is significantly higher than the control and NPS plot soil EC values. Unlikely to $\mathrm{pH}$, the BS-amended plot soil showed a higher percentage of the increment (Fig. 4b) as compared to the background.
This higher EC increment in the BS-treated plot soil may be linked to the occurrence of soluble salt in the BS. Similar to the present study, Saviozzi et al. (1994) observed that the higher proportions of winery sludge increase soil salinity, which exerts severe stress on non-salt-tolerant plants and inhibits the plant growth (Mtshali et al. 2014). But, the soil salinity value found in this study was not at a level that could restrict the plant growth rate and yield of crops. Because the EC value meets the tolerable salinity limit of most plants, it usually ranges from 3 to $4 \mathrm{mS} / \mathrm{cm}$ (Abdullah et al. 2015).

On average, $51.47 \%$ of OC content was obtained from the brewery wastewater sludge-amended soil. When compared with the organic carbon content of the control (50.17\%) and NPS (51.16\%)-fertilized plot soils, it showed insignificant changes. The present study result contradicts Mbagwu (1989) report, who observed that the addition of brewery spent grains improved the organic matter contents of soil significantly. Not only, the organic matter content, other research findings are also reported that an increased addition of OM increases the WHC, exchangeable cation and anions, porosity, nutrient storage and turnover, decreases soil erosion, reduces soil acidity and the microbial activity in the soil through utilizing organic carbon as a source of food and, in general, enhances full health and optimum growth rate of plants (Mtshali et al. 2014; Khanal et al. 2014). The 

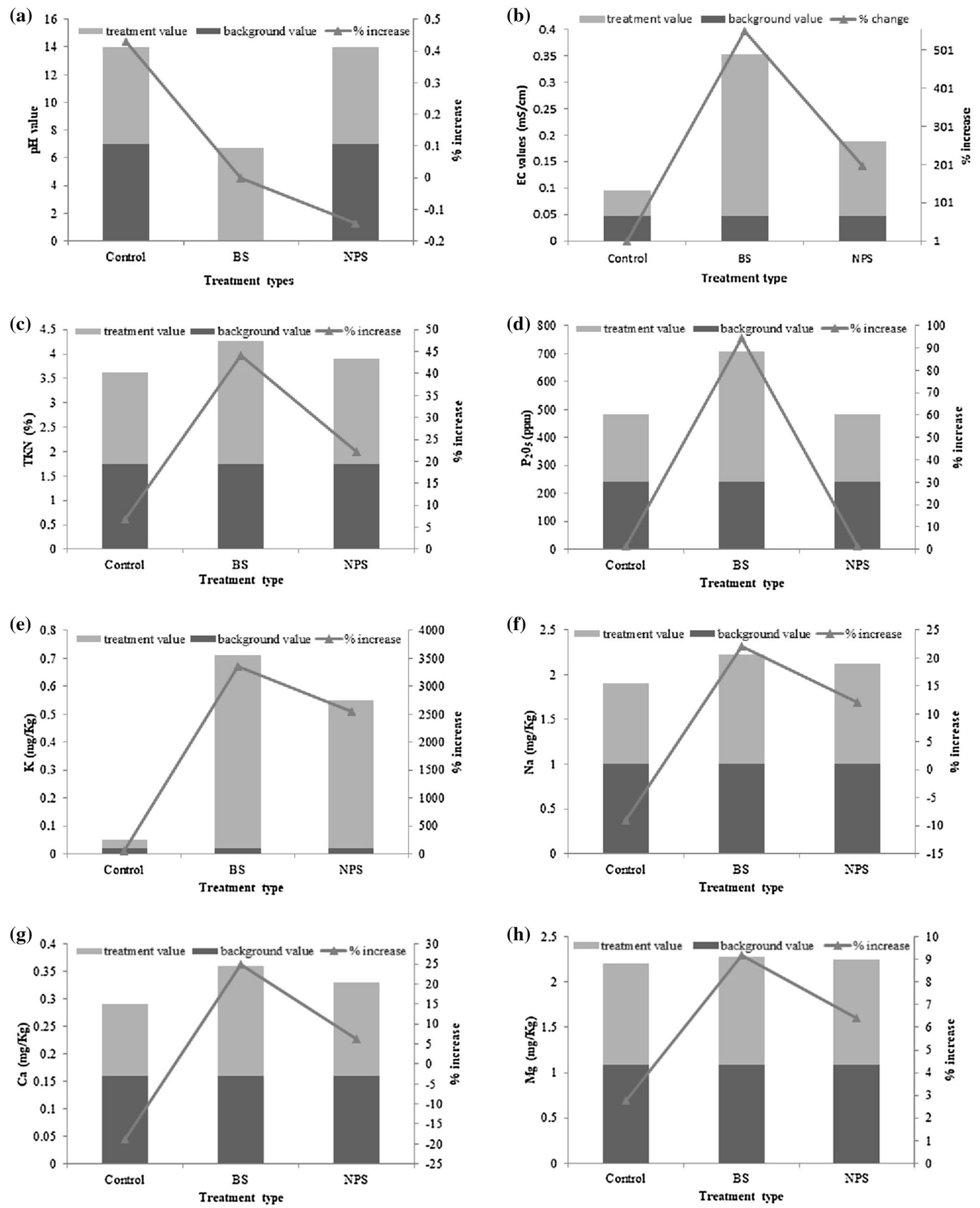

Fig. 4 Change of soil a pH, b EC, $\mathbf{c}$ TKN, $\mathbf{d ~} \mathrm{P}_{2} \mathrm{O}_{5}, \mathbf{e ~ K ,} \mathbf{f} \mathrm{Na}, \mathbf{g} \mathrm{Ca}$ and $\mathbf{h} \mathrm{Mg}$ contents between treatment types and background concentration 
observed insignificant change of OC content in the present study may be probably due to the higher organic content of the background soil which masks the addition of sludge OC content and made unable to know its contribution within this short-term evaluation. The mean WHC of the soil obtained from the BS-treated plot was $86.5 \%$, which changes insignificantly as compared to the control and NPS plot soils. In this study, the OM and WHC showed a similar trend between the treatment plots. In contrary to this study, other researchers reported that an increasing addition of brewery spent grain showed a significant increase in WHC as compared to other treatments (Aboukila et al. 2016) and showed a positive correlation with OM content (key element for an increase in the soil WHC) (Hudson 1994). C/N ratio is another most important characteristic of sludge for reuse because it is important not only for soil health and plant growth, but also for microorganisms in which carbon is a source of energy, while nitrogen is necessary as a building block of cell structure and genetic material as well as proteins synthesis. The literature recommended the accepted range of the $C / N$ ratio is 11 to 20.45 . Hence, the $C / N$ ratio obtained in the sludge-amended plot was 20.42, which fulfills the accepted range and able to support plant species diversity and growth.

Characterization of the soil NPK values indicated that there is a slight increase in the brewery sludge-treated plot soil as compared to the control by 1.35 -fold increase in $\mathrm{N}$; twofold increase in P; and 23-fold increase in K, and NPS by 1.18 -fold increase in $\mathrm{N}$; twofold increase in $\mathrm{P}$; and 1.3fold increase in $\mathrm{K}$ (Table 5). Figure 4c-e shows the effect of application of brewery sludge on the soil NPK content of the background soil and significantly increased the background concentrations of TN by $44 \%, \mathrm{P}_{2} \mathrm{O}_{5}$ by $94.4 \%$ and $\mathrm{K}$ by $3350 \%$; the control TKN by $34.7 \%, \mathrm{P}_{2} \mathrm{O}_{5}$ by $92 \%$ and $\mathrm{K}$ by $2200 \%$; NPS-amended soil TKN by $17.7 \%, \mathrm{P}_{2} \mathrm{O}_{5}$ by $91.7 \%$ and $\mathrm{K}$ by $30.2 \%$. This concluded that the brewery sludge application is effective in improving soil NPK. The minimum total nitrogen and phosphorus value has occurred in the NPS commercial fertilizer-amended plot soil. This may be due to either leaching of these nutrients or easily uptake by maize plants. The enhanced nutrient content in the brewery sludge-amended plot soil of the present study is also concurred the reported result of Ramya et al. (2015) and $\mathrm{Yu}$ et al. (2013), and those achieved enhanced nitrogen and potassium content via higher sludge dosing rate and increased available phosphorus content by application composted poultry manure in the soil, respectively. Likewise, Herencia et al. (2007) also observed the increment of nitrogen, available phosphorus and potassium contents in the organic fertilizer-amended plot than in the untreated one. Hence, sludge amendments can provide these essential nutrients to enrich the soil better than the control and NPSfertilized plot soils. Micronutrients such as magnesium and calcium contents showed insignificant variations between the three treatment groups. However, sodium content significantly varies with the control, and the addition of BS exceeded the sodium content of the control soils by $34.1 \%$. However, the addition brewery sludge increased the sodium background value by $22 \%$, whereas the control sodium content decreased by $9 \%$ from the background concentration (Fig. 4f). Concerning the calcium concentration, the brewery sludge application does not have a significant difference than other treatments, but it increased the background concentration by $25 \%$ when it declined by $18.75 \%$ in the control (Fig. 4g). The calcium and magnesium content found in this study contradicts the finding of Erdem and Suzudogru-Ok (2002) who observed that the addition of brewery sludge showed an increase in the concentrations of exchangeable cations such as $\mathrm{Ca}^{2+}$ and $\mathrm{Mg}^{2+}$. In general, land application of treated plant sludge as a soil conditioner is an attractive option for recycling valuable components such as nitrogen, phosphorus and potassium plant nutrients for agricultural purposes rather than conventional disposal (López-mosquera and Carral 2000; Dolgen et al. 2004; Suárez et al. 2005). Soil pathogen contamination is also a sensitive indicator of soil ecological stressor and environmental pollutions (Mondal et al. 2015). The determination of total fecal coliform (TFC) concentrations in the BS-amended plots soil revealed a higher magnitude than the NPS and control soils. The result revealed $0.94 \pm 0.01 \times 10^{3}, 0.37 \pm 0.01 \times 10^{2}$ and $0.34 \pm 0.01 \times 10^{2} \mathrm{MPN} / \mathrm{ml}$ of TFC, respectively, from BS, control and NPS-treated soil samples; all are less than Canadian regulatory limit (1000 MPN/g) of TFC for total solids. Among the treatments, $24.4 \%$ of TFC was found in the BStreated plot soil samples as compared to the control. This percentage difference involved in the BS-amended plot soil indicates that the addition of BS may be because of contamination of soil with pathogens, and hence, safety measures should be taken in the future to prevent this contamination. Therefore, proper treatment systems should be developing to remove indicator pathogens from the sludge for recycling this nutrient-rich material.

\section{Heavy metals effect on soil}

Trace metal analysis result (Table 5) indicates that insignificant differences were found between the treatments except for lead $(\mathrm{Pb})$ concentration. Among the heavy metals, the available micronutrients such as $\mathrm{Fe}, \mathrm{Cu}$ and $\mathrm{Zn}$ showed insignificant (at $p<0.05$ ) increment by $2.72-, 1.55-$ and 1.34-fold over the control and by 1.61-, 1.25- and 1.75-fold over the NPS-fertilized plot soil samples, respectively. These heavy metals are required at appropriate concentrations for structural and catalytic components of proteins and enzymes as a cofactor and essential for normal growth and development of plant (Gweyi-Onyango and Osei-Kwarteng 2011). However, beyond the optimal level, they also operate a stress 
factor in plants (Karanja 2015). The concentrations of these heavy metals in all the treatment group soils were below the USEPA (1997) maximum permissible limits. This positive outcome of the presence of low levels of heavy metals in the brewery sludge-amended soil can be able to recycle this waste material as a good source of fertilizer for agricultural application in an eco-friendly approach with no risk of heavy metal toxicity in the future. Hence, the application of brewery sludge is able to enrich the soil with micronutrients. The present result agreed with Bhanooduth (2006) finding, who reported that the available micronutrients $(\mathrm{Fe}, \mathrm{Cu}$ and $\mathrm{Zn}$ ) are increased by the addition of compost and organic wastes. However, the accumulation of lead $(\mathrm{Pb})$ in soil was highest, which is 2.5-fold higher than the control and 2.6fold greater than the NPS-fertilized soil samples. In other words, the brewery sludge application increased the lead content of the soil by $150 \%$ over the control and $156.7 \%$ over the NPS-fertilized plot soils. This implicates that treatment soils receiving brewery sludge resulted in the higher lead concentrations, which was significantly higher than the control $(p=0.00105)$ and the NPS fertilizer $(p=9.54378 \mathrm{E}-4)$ treated plot soils. The probable source of lead in the brewery sludge may be due to emission from the exhaust pipe of the generating plant used to power the machines during production. Similar to this study, Khanal et al. (2014) reported that an increased application rate of BS increased the greater accumulation of heavy metals in the vegetation tissues and soils. Even if the short-term residual effect meets the permissible standards in the soil, future study should be considered the long-term application of the sludge residual effects on the soil and crops produce.

\section{Conclusion}

Characterization of the Kombolcha brewery sludge revealed the presence of essential soil macro- and micronutrients. The field-scale experimental demonstration result showed a promising result in the production of more maize biomass and grain yields under the BS-amended plot than the NPS fertilizer-treated and control plots. The preliminary shortterm study reveals that brewery sludge has good potential to be exploited in crop production, improving soil properties particularly soil nitrogen, phosphorus and potassium contents. However, the future long-term study is essential to monitor any possible adverse effect in terms of toxic metals, persistent organic pollutants and pathogen status in soil and crop production and transfer of antibiotic resistance genes in the soil environment and human gut resistome through the application of dewatered sludge as agricultural fertilizers.

Acknowledgements The authors honestly acknowledge the head of the factory administrative director, Ato Melaku Wube, for his patience, friendly approach and collaboration for the accomplishment of the work through regular field visit and supplying necessary materials for the experiment. The authors also likely to express their deep gratitude to individuals: Mrs. Abera, soil expert who guided us in the field work, and Yesuf Hassen (farmer) for his interest and collaborative work to test this field experiment in his farmland.

\section{Compliance with ethical standards}

Conflict of interest The authors declare that they have no conflict of interest.

Open Access This article is licensed under a Creative Commons Attribution 4.0 International License, which permits use, sharing, adaptation, distribution and reproduction in any medium or format, as long as you give appropriate credit to the original author(s) and the source, provide a link to the Creative Commons licence, and indicate if changes were made. The images or other third party material in this article are included in the article's Creative Commons licence, unless indicated otherwise in a credit line to the material. If material is not included in the article's Creative Commons licence and your intended use is not permitted by statutory regulation or exceeds the permitted use, you will need to obtain permission directly from the copyright holder. To view a copy of this licence, visit http://creativecommons.org/licenses/by/4.0/.

\section{References}

Abdullah R, Ishak CF, Kadir WR, Bakar RA (2015) Characterization and feasibility assessment of recycled paper mill sludges for land application concerning the environment. International Journal of Environmental Research and Public Health. https:// doi.org/10.3390/ijerph120809314

Aboukila EF, Nassar IN, Rashad M, Hafez M, Norton JB (2016) Reclamation of calcareous soil and improvement of squash growth using brewers' spent grain and compost. Journal of the Saudi Society of Agricultural Sciences. https://doi.org/10.1016/j.jssas .2016.09.005

Akongwubel AO, Ewa UB, Prince A, Jude O, Martins A, Simon O, Nicholas O (2012) Evaluation of agronomic performance of Maize (Zea mays L.) under different rates of poultry manure application in an Ultisol of Obubra, Cross River State, Nigeria. International Journal of Agriculture and Forestry 2(4):138-144. https://doi.org/10.5923/j.ijaf.20120204.01

Alayu E, Yirgu Z (2017) Advanced technologies for the treatment of wastewaters from agro-processing industries and cogeneration of by-products: a case of slaughterhouse, dairy and beverage industries. Int J Environ Sci Technol 15(7):1581-1596. https:// doi.org/10.1007/s13762-017-1522-9 
Alayu E, Leta S, Aragaw T (2018) Characterization of the physicochemical and biological properties of Kombolcha brewery wastewater treatment plant bio-solid in relative to agricultural uses. Advances in Recycling and Waste Management 3(1):1-7. https://doi.org/10.4172/2475-7675.1000154

Alemu N, Ahmed A, Mohammed M (2017) Impact of brewery waste sludge on Sorghum (Sorghum bicolor L. Moench) productivity and soil fertility in Harari Regional State, Eastern Ethiopia. Turkish Journal of Agriculture Food Science and Technology 5(4):366-372

Al-Mahasneh M, Al-Widyan M, Ababneh H, Rababah T, Ereifej K (2008) Grain dust as an energy and food resource. Nat Resour Res. https://doi.org/10.1007/s11053-008-9060-2

APHA (1999) Standard methods for the examination of water and wastewater. APHA, Washington DC

Arthurson V (2008) Mini review: proper sanitization of sewage sludge: a critical issue for a sustainable society. Appl Environ Microbiol 74(17):5267-5275. https://doi.org/10.1128/ AEM.00438-08

Asia IO, Ekpo KE, Chukwuedo ME (2008) Economic importance and application options of some industrial sludge conditioned by different treatment methods. Afr J Biotech 7:2434

Babel S, Sae-Tang J, Pecharaply A (2009) Anaerobic co-digestion of sewage and brewery sludge for biogas production and land application. Int. J. Environ. Sci. Tech. 6(1):131-140

Bhanooduth L (2006) The effect of sugar industry wastes on extractable heavy metals in soil. In: Soil care and quality soil management, the 18th world congress of soil science, pp 136-139

Bremner JM, Mulvaney CS (1982) Nitrogen-total. In: Page AL et al (eds) Methods of soil analysis: part 2, 2nd edn. American Society of Agronomy, Madison, pp 595-624

Canadian Council of Ministers of the Environment (1995) Guidelines for compost quality. CCME, Winnipeg (ISBN 1-896997-60-0)

Chen Q, An X, Li H, Su J, Ma Y, Zhu Y (2016) Long-term field application of sewage sludge increases the abundance of antibiotic resistance genes in soil. Environ Int 93:1-10. https://doi. org/10.1016/j.envint.2016.03.026

Cheraghi M, Sobhanardkani S, Lorestani B (2015) Effects of sewage sludge and chemical fertilizers on $\mathrm{Pb}$ and $\mathrm{Cd}$ accumulation in Fenugreek (Trigonella gracum). Iranian Journal of Toxicology 9(30): $1-5$

Dolgen D, Alpaslan MN, Delen N (2004) Use of an agro-industry treatment plant sludge on iceberg lettuce growth. Ecol Eng 23:117125. https://doi.org/10.1016/j.ecoleng.2004.07.006

Edgell K (1989) USEPA method study 37 SW-846 method 3050 acid digestion of sediments, sludges, and soils. Environmental Monitoring Systems Laboratory, United State Environmental Protection Agency, Washington, DC
EPA (1994) A plain english guide to the EPA: part 503 Biosolids Rule. Environmental Protection Agency, Office of Wastewater Management, Washington DC

Erdem N, Suzudogru-Ok S (2002) Effect of brewery sludge amendments on some chemical properties of acid soil in pot experiments. Bio-resource Technology 84:271-273

Fillaudeau L, Blanpain-avet P, Daufin G (2006) Water, wastewater and waste management in brewing industries. J Clean Prod 14:463471. https://doi.org/10.1016/j.jclepro.2005.01.002

Gweyi-Onyango JP, Osei-Kwarteng M (2011) Safe vegetable production with wastewater in developing countries: demystifying the negative notions. African Journal of Horticultural Science 5:70-83

Herencia JF, Ruiz-Porras JC, Melero S, Garcia-Galavis PA, Morillo $\mathrm{E}$, Maqueda C (2007) Comparison between organic and mineral fertilization for soil fertility levels, crop macronutrient concentrations, and yield. Agron J 99:937-983

Hseu YZ (2004) Evaluating heavy metal contents in nine composts using four digestion methods. Bio-resource Technology 95:53-59

Hudson BD (1994) Soil organic matter and available water holding capacity. J Soil Water Conserv 49:189-194

Jolly G, Ashwani K (2012) Effect of different soil types on growth and productivity of Euphorbia lathyrisl, a hydrocarbon yielding plant. International Journal of Life Science and Pharma Research 2(3):164-173

Kanagachandran K, Jayaratne R (2006) Utilization potential of brewery wastewater sludge as organic fertilizer. J Inst Brew 112:92-95

Karanja MP (2015) Suitability of waste water sludge for agricultural use: a case study of ruai sewage treatment plant, Nairobi, Kenya. M.Sc. thesis, School of Environmental Studies of Kenyatta University, N50/CTY/PT/23012/2011

Khanal BR, Shah SC, Sah SK, Shriwastav CP (2014) Heavy metals accumulation in cauliflower (Brassica Oleracea L. var. Botrytis) grown in brewery sludge amended sandy loam soil. IJAST 2(3):87-91. https://doi.org/10.14355/ijast.2014.0203.01

López-mosquera E, Carral EV (2000) Use of dairy-industry sludge as fertilizer for grasslands in northwest Spain: heavy metal levels in the soil and plants. Resour Conserv Recycl 30(2000):95-109. https://doi.org/10.1016/S0921-3449(00)00058-6

Government of Maharashtra (2009) Laboratory testing procedure for Soil and water sample analysis. Document no. SSD/GL.01, Water Resources Department, Directorate of irrigation research \& development, Pune

Mbagwu JSC (1989) Effects of organic amendments on some physical properties of a tropical ultisol. Biological Wastes 28:1-13

Mondal S, Singh RD, Patra AK, Dwivedi BS (2015) Changes in soil quality in response to short-term application of municipal sewage sludge in a typic haplustept under cowpea-wheat cropping 
system. Environmental Nanotechnology, Monitoring \& Management 4(2015):37-41

Mtshali JS, Tiruneh AT, Fadiran AO (2014) Characterization of sewage sludge generated from wastewater treatment plants in Swaziland concerning agricultural uses. Resources and Environment 4(4):190-199. https://doi.org/10.5923/j.re.20140404.02

Oljira T, Muleta D, Jida M (2017) Potential applications of some indigenous bacteria isolated from polluted areas in the treatment of brewery effluents. Biotechnology Research International 2018:113. https://doi.org/10.1155/2018/9745198

Olsen SR, Cole CY, Watanable FS, Dean LA (1954) Estimation of available phosphorus in soils by extraction with sodium bicarbonate. USDA Circular No. 939, U.S. Government Publishing Office, Washington, DC, pp 1-19

Omoyeni OA, Moronkola BA (2012) Pollution status of brewery sewage sludge in Lagos. IJRRAS 10(1):159-165

Pribyl DW (2010) A critical review of the conventional SOC to SOM conversion factor. Geoderma 156:75-83. https://doi.org/10.1016/j. geoderma.2010.02.003

Rajagopal R, Saady CMN, Torrijos M, Thanikal VJ, Hung TY (2013) Sustainable agro-food industrial wastewater treatment using high rate anaerobic process. Water 5:292-293

Ramya N, Srinivas T, Aruna Lakshmi K (2015) Studies on effect of brewery wastewater sludge (BS) on morphology and yield of chilly (Capsicum annum L.) plant. International Journal of Pharmaceutical Sciences and Research 6(1):405-409

Saviozzi A, Riffaldi R, Cardelli R (1994) Suitability of a winerysludge as soil amendment. Biores Technol 49:173-178

Skene TM, Oades JM, Kilmore G (1995) Water treatment sludge: a potential plant growth medium. Soil Use Manage. 11:29-33

Spinosa L, Vesilind PA (2001) Sludge into bio-solids. IWA Publishing, London

Suárez PC, Seoane S, Mosquera EL, Merino A (2005) Dairy industry sewage sludge as a fertilizer for an acid soil: a laboratory experiment with Lolium multiflorum L. Spanish Journal of Agricultural Research 2(3):419-427

Thomas KR, Rahman PKSM (2006) Brewery wastes. Strategies for sustainability, a review. Aspects of Applied Biology 80:147-153

USEPA (1997) Exposure factors handbook. EPA, Washington, DC

Wendimagegn E (2016) The fertilizing potential of breweries waste water sludge compared to urea on the growth and yield of tomato plant. M.Sc. thesis, Addis Ababa University, College of Natural Sciences, Center for Environmental Science Program

Yu W, Ding X, Xue S, Li S, Liao X, Wang R (2013) Effects of organicmatter application on phosphorus adsorption of three soil parent materials. J Soil Sci Plant Nut 13:1003-1017 